\title{
Al Gore \\ The Future. Six drivers of global change New York 2013, ss. 592
}

$\mathbf{M}$ ało jest pośród ludzi polityki i ekologii takich, którzy poświęcają całą swoją pracę wyłącznie jednej idei. Skupiają się na niej w trakcie pełnienia funkcji, a także w ramach swej niezawodowej działalności. Do takich ludzi należy były wiceprezydent Stanów Zjednoczonych i laureat Pokojowej Nagrody Nobla - Al Gore. Od początku swej kariery skupił się na informowaniu i zwalczaniu globalnego ocieplenia. Jest autorem kilkunastu książek i setek artykułów, w których porusza tę tematykę, obok zagadnień funkcjonowania społeczeństwa na wszystkich poziomach strukturalnych w dobie zmian klimatycznych, rodzącego się korporacjonizmu i szybkiego rozwoju technologicznego.

Jego najnowsza książka: The Future. Six drivers of global change jest kolejnym zbiorem rozważań na temat przyszłości globalnego społeczeństwa. W odróżnieniu jednak od swych poprzednich publikacji, Gore skupia się na strukturach makrospołecznych, ze szczególnym uwzględnieniem ludzkości jako całości. Autor już we wstępie zaznacza, że poglądy zawarte w książce są efektem jego własnych przemyśleń i ich rewizji pod naciskiem zachodzących zmian.

Jak wskazuje tytuł recenzowanej pozycji, Gore analizuje sześć czynników, które jego zdaniem już obecnie rozpoczęły proces przeobrażeń w społeczeństwie, rozumianych przez niego jako Globalna Wioska. Pierwszym z nich jest powstanie światowej ekonomii, którą autor prezentuje jako sieć ściśle ze sobą połączonych gospodarek poszczególnych państw. Istnienie i funkcjonowanie powiązań w tej sieci jest gwarantem funkcjonowania jej poszczególnych elementów. Jako drugi czynnik autor wymienia powstanie i rozwój światowej sieci cyfrowej, która będzie zawierać wiedzę i emocje wszystkich ludzi na Ziemi, a także istot sztucznych - robotów i SI ${ }^{1}$. Trzecim

SI - akronim od słów Sztuczna Inteligencja. Polski odpowiednik angielskiego Artificial Intelligence (AI). 
czynnikiem jest cykl przeobrażeń prowadzących do zachwiania równowagi geopolitycznej, w której funkcje hegemona stanowią Stany Zjednoczone stojące na czele ONZ i powstanie wielu centrów regionalnej władzy politycznej (przy jednoczesnej dyspersji hegemonicznych rządów na kilka, położonych na różnych kontynentach, ośrodków politycznych). Kolejnym, czwartym czynnikiem jest niekontrolowany wzrost różnych determinantów, wśród których wymienia między innymi populacje, urbanizacje i zanieczyszczenia. Przedostatnim czynnikiem, mającym według autora w przyszłości drastyczny wpływ na przekształcenia w społeczeństwie, jest odkrycie i wykorzystanie materiałów, które mogą być opracowywane na poziomie molekularnym i co za tym idzie - rozwój nanotechnologii, biotechnologii i inżynierii genetycznej. Jako ostatni czynnik, Gore podaje przemiany w relacjach między człowiekiem i środowiskiem, w którym on żyje w celu zahamowania jego degradacji i odnowienia elementarnych funkcji środowiska naturalnego w korelacji z rozwojem ludzi.

$\mathrm{Na}$ podstawie tych sześciu wyznaczonych czynników powstała struktura recenzowanej książki - każdy z sześciu rozdziałów po kolei je analizuje na gruncie nauk społecznych.

W rozdziale pierwszym, zatytułowanym: Earth Inc. (co można tłumaczyć jako Korporacja Ziemia) autor przedstawia i analizuje elementy składowe obecnego dominującego systemu gospodarczego, czyli kapitalizmu. Jednocześnie wskazuje na czynniki, które mają najbardziej negatywny wpływ na rozwój ekonomiczny będąc poniekąd wyznacznikami trwającego światowego kryzysu gospodarczego oraz zwiększających się nierówności społecznych, w tym zaniku klasy średniej. Wśród tych czynników na pierwszym miejscu wyznacza outsourcing, czyli przenoszenie miejsc pracy do krajów o niższych kosztach wytworzenia danego dobra, a także robosourcing, czyli zastępowanie pracowników maszynami. W tym miejscu autor nie przekreśla całkowicie roli maszyn w funkcjonowaniu zdrowej gospodarki. Wskazuje natomiast na pewne granice, które należałoby narzucić naukowcom by społeczeństwo nie czuło się zastępowane robotami. Jednocześnie omawiając kwestie technologii w gospodarce, poruszył autor ważny, aczkolwiek pomijany, temat hiperszybkich łączy internetowych przeznaczonych wyłącznie do przeprowadzania transakcji między giełdami. Ubolewa tym samym nad marnotrawieniem milionów dolarów tylko w celu zmniejszenia czasu między kolejnymi transakcjami o milisekundy, co nie zawsze prowadzi do zamierzonych skutków. Autor pokazuje także, jak drastycznie negatywne skutki ma powiększająca się różnica między udziałem w PKB danego kraju. Nawiązując do oddolnych społecznych ruchów jako Occupy Wall Street i historycznych transformacji ośrodków rozwoju technologicznego, autor w recenzowanej pozycji stara się pokazać, jak ważna dla przyszłości globalnego społeczeństwa jest zmiana paradygmatów ekonomii poszczególnych podzespołów światowej gospodarki - od zrozumienia, że „pracuje się by żyć”, a nie odwrotnie, przez kontrolę nad niezależnymi od władzy państwowej korporacjami, aż po rozwój światowych szlaków handlowych.

Drugi rozdział recenzowanej pozycji dotyczy rozwoju światowej sieci cyfrowej i został zatytułowany Global Mind. W nim to autor rozważa „za” i „przeciw” powstaniu Internetu jako repozytorium wiedzy jaką społeczeństwa i ludzie zdołali zdobyć przez tysiąclecia, od momentu wynalezienia pisma. Analizuje między innymi tzw. Efekt 
Gutenberga, który określa jako zanik zdolności do zapamiętywania skomplikowanych tekstów w związku z wynalezieniem druku, a następnie Internetu. Tym samym powstaje miejsce, gdzie zawsze można poszukać odpowiedzi na konkretne pytanie. Jako inny czynnik „przeciw” rozwojowi globalnej sieci, wskazuje także na osłabioną prywatność korzystających z jej zasobów osób. Co ciekawe, autor staje w obronie osób, u których następstwem czynów jest upublicznienie na przykład danych osobowych - wskazuje, że takie transparentne zachowanie jest charakterystyczne dla młodego pokolenia, które postrzega Internet jako integralną część życia. Wręcz mówi o konieczności pogodzenia się z faktem swobodnego dysponowania swą prywatnością przez nowe, cyfrowe pokolenie. W ostateczności staje jednak na stanowisku, że tylko dzięki rozwojowi sieci komunikacyjnej społeczeństwa świata będą w stanie funkcjonować w pokoju tworząc wydajną gospodarczo, politycznie i naukowo Globalną Wioskę.

Rozdział kolejny analizuje przemiany w światowej geopolityce. Wskazując na kilka wrażliwych punktów, Gore stara się zobrazować drogę, jaką będzie musiało przejść społeczeństwo w ciągu najbliższych kilkudziesięciu lat. Tym samym wskazuje na (między innymi) rosnącą rolę Chin i upadek Stanów Zjednoczonych jako globalnego hegemona, wzrost znaczenia międzynarodowych korporacji oraz integracje państw w ramach regionalnych organizacji międzynarodowych. Jednocześnie autor pokazuje, że wraz ze wzrostem integracji, będzie zwiększał się wpływ organizacji na życie obywateli w poszczególnych państwach członkowskich.

Niekontrolowany wzrost wielu różnych czynników jest tematem analizy kolejnego, czwartego rozdziału książki The Future. Six drivers of global change. W tej części autor powoli przechodzi do zagadnień, którymi zajmował się w swych poprzednich publikacjach - ekologii, zrównoważonego rozwoju i samowystarczalności globalnego społeczeństwa. Oprócz więc stricte elementów związanych z tymi zagadnieniami, jak zanieczyszczenie środowiska i idące za tym jego przeobrażenie, autor porusza kwestie kontroli pewnych zachowań w społeczeństwie. Kontrola taka, prowadzona zgodnie z zasadami etycznymi, miałaby regulować wzrost populacji, zdrowie oraz edukację członków danego społeczeństwa i tym samym ich produktywność oraz procesy migracyjne, które według autora powodują wzrost napięć społecznych i tym samym prowadzą do zaniku więzi społecznych. Niestety autor nie wspomina ani razu o etyce takiej kontroli.

W piątym rozdziale Gore porusza tematykę rozwoju nowych i emergentnych technologii, jak między innymi tworzenie wytrzymałych materiałów w nanoskali, których właściwości fizyczne wkraczają poza znane do tej pory rozwiązania. Analizuje też zastosowanie inżynierii genetycznej, w tym także klonowania i digitalizacji życia do poprawy zdrowia, przezwyciężenia słabości ludzkiego organizmu, a nawet pokonania śmierci. Choć autor stara się pokazać walory takich rozwiązań, to błędem jest brak szerszego zainteresowania ruchem filozoficzno-społecznym jakim jest transhumanizm, który to właśnie postuluje wykorzystanie tych technologii do pokonania ograniczeń ludzkiego ciała. Autor wspomina o istnieniu takiego ruchu, ale nie poświęca mu większej uwagi, choć to właśnie zaangażowani w niego ludzie odpowiadają za wiele sukcesów technologicznych. Wydaje się także błędne zmieszanie pojęcia „technologicznej osobliwości” ${ }^{\prime 2}$ transhumanizmem.

2 Technologiczna osobliwość (ang. singularity) - powstanie rozwiniętej i samoewoluującej Sztucznej 
W ostatnim rozdziale autor wraca do znanej ze swych poprzednich publikacji retoryki ekologicznej. Wskazuje on na konsekwencje działalności człowieka, które doprowadzają do Globalnego Ocieplenia. Odnosi się z lekceważeniem do badań niepotwierdzających jego teorii proekologicznych. Jednocześnie wzywa społeczeństwo Globalnej Wioski do podjęcia działań na rzecz ograniczenia wydalania dwutlenku węgla. Książkę kończy bogata bibliografia, wśród której niestety brak pozycji, które podważałyby teorie autora.

Recenzowana pozycja jest dobrym podsumowaniem celów do których dąży autor w swej politycznej i społecznej działalności. Prócz tego, prezentuje ona także nowe kierunki badań. Autor, omawiając każde zagadnienie, stara się pokazać przeszły i obecny stan badań. Każde analizowane zjawisko pokazywane jest w płaszczyźnie czasowej, czyli - jak wyglądało kiedyś w porównaniu do teraźniejszości, oraz w płaszczyźnie geograficznej - przez ukazanie funkcjonowania danego zjawiska w różnych miejscach na świecie.

Przy każdym czynniku Gore prezentuje szereg danych statystycznych i ekonomicznych. Sam jednak pozostaje bezkrytyczny wobec podważenia swych badań dotyczących Globalnego Ocieplenia, które miało miejsce kilka lat temu wraz z ujawnieniem manipulowania danymi przy omawianiu tego zjawiska. Tym samym ostra reakcja autora wobec krytyków jego teorii, znajdująca swój wyraz wyłącznie w niepopartym żadnymi dowodami negowaniu wyników badań tych krytyków, częściowo podważa wiarygodność

Inteligencji, która przekroczy ograniczenia ludzkiego mózgu do gromadzenia i analizy danych i osiągnie poziom wyższej inteligencji niż ludzka, wykraczając poza nasze zozumienie. autora jako badacza. Także w odróżnieniu od innych rozdziałów recenzowanej pozycji, w rozdziale szóstym autor przytacza wyniki sprzed 20 lat. Tymczasem $\mathrm{w}$ innych rozdziałach posiłkuje się danymi nowymi, rzadko starszymi niż pół dekady. Dodatkowym minusem recenzowanej pracy jest drastyczna zmiana języka z naukowego na pełen agresywnych tonów $\mathrm{w}$ rozdziale szóstym. Bez cienia wątpliwości można powiedzieć, że recenzowana książka nic by nie straciła na naukowej wartości, gdyby wyłączyć z niej ten rozdział.

Pewne zastrzeżenia można mieć także do układu książki. Choć tytuły rozdziałów odpowiadają wspomnianym już w tytule czynnikom i zasadniczo ich tematyka także nie odbiega od przyjętych zagadnień, to czasami zdarza się, że problemy poruszane w podrozdziałach nie dotyczą całego rozdziału (ma to na przykład miejsce przy omawianiu niekontrolowanego wzrostu populacji w rozdziale czwartym przy opisaniu w podrozdziale rozwoju marketingu masowego). Dopiero więc całościowe ujęcie recenzowanej pozycji, nie przez pryzmat poszczególnych rozdziałów, a książki jako całości, pozwala zrozumieć role jakie mają odegrać omawiane czynniki w tworzeniu społeczeństwa przyszłości.

Całościowe ujęcie tematyki, prognozowanie na temat przyszłości na podstawie prawdziwych danych i trendów, stanowi o tym iż jest to książka wyjątkowa. Recenzowana praca jest dobrą, aczkolwiek nie pozbawioną wad, próbą analizy społeczeństwa przyszłości, opartą o wnioskowanie na podstawie danych. Wady rozdziału szóstego rekompensowane są przez pozostałą zawartość publikacji. Autor prezentuje czytelnikowi w klarowny sposób swe poglądy starając się uzmysłowić jak koniecz- 
ne są zmiany w społeczeństwie, nie tylko amerykańskim, by osiągnąć założone cele pokoju, zrównoważonego rozwoju i dobrobytu. Książka po dogłębnej analizie może z powodzeniem służyć jako prezentacja działań jakie powinna podjąć ludzkość by osiągnąć cel jakim jest przekształcenie jej w Globalną Wioskę. 